\title{
PENGARUH MENGHAFAL AL-QUR'AN TERHADAP HASIL BELAJAR MAHASISWA PROGRAM STUDI PAI FITK IAIN AMBON
}

\author{
Syahrudin ${ }^{1}$, Yusuf Abdurachman Luhulima ${ }^{2}$, Nur Khozin ${ }^{3}$ \\ Program Studi Pendidikan Agama Islam FITK IAIN Ambon \\ syahsyahruddin72@gmail.com Yusuf.luhulima@iainambon.ac.id, \\ khozinpai@gmail.com
}

\begin{abstract}
The purpose of this study was to determine whether there is an influence between the ability to memorize the Qur'an and learning outcomes. This research is descriptive quantitative by taking samples of students of the Islamic Religious Education Study Program IAIN Ambon Class of 2017-2018. The sampling technique used by the researcher was purposive sampling and used instruments in the form of observation, questionnaires and documentation, then the research results were analyzed using simple linear regression analysis. Success in achieving satisfactory learning outcomes and continuously increasing is strongly supported by internal and external factors. Al-Qur'an memorization activities have a positive impact that is a supporting factor for success in learning such as the ability of brain sharpness, discipline in learning, good memory, improving a good mindset and ease of understanding learning material. By referring to the results of the hypothesis test, it is known that $\mathrm{Ha}$ is accepted and Ho is rejected by obtaining a tcount value of 2,536 table which has been set at 2,040, and the magnitude of the effect of memorizing the Qur'an on learning outcomes is $17.2 \%$ and the rest is 82 , $8 \%$.
\end{abstract}

\section{Keywords: The Effect of Memorizing the Qur'an and Learning Outcomes}

Abstrak: Tujuan penelitian ini adalah untuk mengetahui adakah pengaruh antara kemampuan menghafal Al-Qur'an dengan hasil belajar. Penelitian ini adalah deskriptif kuantitatif dengan mengambil sampel Mahasiswa Program Studi Pendidikan Agama Islam IAIN Ambon Angkatan 2017-2018. Adapun teknik pengambilan sampel yang digunakan oleh peneliti adalah purposive sampling serta menggunakan instrumen berupa observasi, angket dan dokumentasi, kemudian hasil penelitian dianalisis dengan menggunakan analisis regresi linier sederhana. Keberhasilan dalam meraih hasil belajar yang memuaskan dan terus meningkat sangat didukung oleh faktor internal dan faktor eksternal. Kegiatan menghafal al-Qur'an memberikan dampak positif yang menjadi faktor pendukung keberhasilan dalam belajar seperti kemampuan ketajaman otak, kedisiplinan dalam belajar, daya ingat yang baik, meningkatkan pola pikir yang baik dan kemudahan dalam memahami materi pembelajaran. Dengan merujuk kepada hasil uji hipotesis diketahui bahwa Ha diterima dan Ho ditolak dengan memperoleh nilai thitung yaitu 2,536 $\geq$ $t_{\text {tabel }}$ yang telah ditetapkan sebesar 2,040, dan memperoleh besarnya pengaruh menghafal al-Qur'an terhadap hasil belajar adalah sebesar $17,2 \%$ dan sisanya yaitu $82,8 \%$.

Kata Kunci: Pengaruh Menghafal al-Qur'an dan Hasil Belajar

\section{PENDAHULUAN}

\section{Latar Belakang}

Pendidikan sangat penting bagi kehidupan manusia, karena pendidikan sendiri mempunyai peran sentral dalam mendorong individu dan masyarakat untuk meningkatkan kualitasnya dalam segala aspek 
kehidupan demi mencapai kemajuan dan untuk menunjang perannya di masa yang akan datang.

Socrates mengatakan bahwa "pendidikan merupakan proses pengembangan manusia ke arah kearifan, pengetahuan, dan etika. Oleh karenanya membangun aspek kognitif, afektif, dan psikomotorik secara seimbang dan berkesinambungan adalah nilai pendidikan yang paling tinggi" (Zaim Elmubarok, 2009). Pernyataan ini sejalan dengan sistem pendidikan yang digunakan di Indonesia sebagaimana yang tercantum di dalam Undang-Undang Sistem Pendidikan Nasional pasal 1 UU RI No. 20 tahun 2003.

Dalam Undang-Undang Sistem Pendidikan Nasional pasal 1 UU RI No. 20 tahun 2003, dinyatakan bahwa "pendidikan adalah usaha sadar dan terencana untuk mewujudkan suasana belajar dan proses pembelajaran agar peserta didik secara aktif mengembangkan potensi dirinya untuk memiliki kekuatan spiritual keagamaan, pengendalian diri, kepribadian, kecerdasan, akhlak mulia serta keterampilan yang dibutuhkan dirinya, masyarakat bangsa dan negara" (Hasbullah, 2003).

Bahkan dalam agama Islam, perintah pertama kali turun adalah untuk menuntut ilmu atau harus berpendidikan. Sebagaimana disebutkan dalam QS. al-Alaq/96:1-5 Rasulullah SAW diperintahkan untuk membaca. Terjemahnya:

"Bacalah dengan (menyebut) nama Tuhanmu yang menciptakan, Dia telah menciptakan manusia dari segumpal darah. Bacalah, dan Tuhanmulah Yang Maha mulia, Yang mengajar (manusia) dengan pena. Dia mengajarkan manusia apa yang tidak diketahuinya" (Kementerian Agama RI, 2015).

Pendidikan menekankan pengembangan kekuatan spiritual dan akhlak mulia sebagaimana yang tercantum dalam Undang-Undang sistem pendidikan Nasional pasal 1 UU RI No. 20 tahun 2003, maka selayaknya setiap peserta didik untuk mengikuti petunjuk al-Qur'an dan Hadits.

Al-Qur'an diturunkan untuk dijadikan petunjuk, bukan hanya untuk umat Islam, melainkan diturunkan untuk semua manusia hingga akhir zaman. Oleh karena itu, diperlukan upaya-upaya terarah dan terstruktur 
dikalangan umat muslim untuk menjaga keaslian ayat-ayat al-Qur'an seperti yang diturunkan Allah SWT kepada Nabi Muhammad SAW. Terdapat banyak cara dalam upaya menjaga keaslian ayat-ayat al-Qur'an agar tetap terjaga yaitu salah satunya dengan cara menghafalnya.

Membimbing mahasiswa untuk menghafal al-Qur'an adalah salah satu hal yang penting dan baik. Al-Hafizh as-Suyuthi berkata bahwa pengajaran al-Qur'an adalah dasar dari prinsip-prinsip Islam. Dampak positif dari kegiatan menghafal adalah akhlak peserta didik semakin baik dari sebelumnya. Seorang peserta didik yang mampu menghafal al-Qur'an pun lebih tekun dalam menunaikan shalat berjamaah di masjid, lebih berbakti kepada orang tua, dan lebih hormat kepada sesama. Hal itu karena sebenarnya al-Qur'an bukan sekedar dihafal, melainkan memang tujuan yang utama adalah agar al-Qur'an itu menjadi perilaku dan moral bagi manusia.

Dalam menghafalkan al-Qur'an hingga benar-benar melekat pada ingatan tentu bukanlah hal yang mudah untuk diraih, sehingga diperlukan perhatian khusus agar dapat menghafalnya dengan sempurna dan lancar. Seseorang yang ingin menghafal al-Qur'an harus disiplin dan istiqomah dalam menambah hafalan, menjaga hafalannya dan hendaknya selalu bersemangat setiap waktu dan menggunakan waktu luangnya untuk menambah hafalan, mengulangi hafalan dan melakukan kegiatan yang dapat membantu memperkuat hafalan al-Qur'annya.

Dunia pendidikan diperlukan aktivitas khusus dalam belajar agar dapat mendorong mahasiswa untuk menghafal al-Qur'an dan mendapatkan hasil belajar yang memuaskan. Hasil belajar merupakan hal yang sangat penting dalam pendidikan. Karena dengan hasil belajar, kita dapat mengukur sejauh mana pemahaman peserta didik terhadap materi yang diberikan oleh seorang pendidik. Hasil belajar adalah penilaian hasil usaha kegiatan belajar yang dinyatakan dalam bentuk simbol, angka, huruf maupun kalimat yang dapat mencerminkan hasil yang sudah dicapai 
oleh setiap anak dalam periode tertentu (Muhammad Fathurrohman dan Sulistyorini, 2012).

Salah satu faktor yang mempengaruhi hasil belajar adalah minat dan perhatian mahasiswa. Minat memiliki pengaruh yang besar terhadap hasil belajar. Apabila seseorang mempunyai minat yang tinggi terhadap materi yang akan dipelajari, maka mahasiswa tersebut akan terus berusaha dalam mempelajarinya, sehingga apa yang diinginkannya dapat tercapai sesuai dengan yang diharapkan. Untuk dapat belajar dengan baik, seorang anak harus ada perhatian terhadap materi pelajaran yang akan dipelajarinya. Perhatian juga berpengaruh terhadap hasil belajar. Untuk menjamin hasil belajar yang baik, maka mahasiswa harus mempunyai perhatian terhadap bahan yang dipelajarinya.

Orang yang memiliki minat terhadap suatu mata pelajaran atau mata kuliah, maka dia akan senantiasa termotivasi untuk mengikuti proses pembelajaran dan mempelajari materi yang diberikan meskipun yang dirasakan rumit. Sebaliknya jika seseorang memiliki minat yang rendah, maka semangat atau motivasi untuk mempelajari mata kuliah atau mata pelajaran tersebut akan menjadi rendah pula. Agar dapat memahami mata kuliah atau mata pelajaran yang diberikan oleh seorang pendidik, maka mahasiswa harus berkonsentrasi dalam memusatkan perhatiannya kepada pendidik yang sedang menerangkan materi pembelajaran atau bahan ajar yang akan dipelajari.

Kampus IAIN Ambon merupakan Perguruan Tinggi Islam dibawah naungan Kementerian Agama RI yang terletak di kota Ambon, tepatnya di Kecamatan Sirimau Desa Batu Merah. yang mana Rektor IAIN Ambon mewajibkan kepada seluruh mahasiswa yang telah terdaftar sebagai mahasiswa di kampus IAIN Ambon, untuk mengikuti pembinaan baca-tulis al-Qur'an termasuk didalamnya menghafal al-Qur'an melalui SK Rektor No. 14 Tahun 14 tentang standarisasi kompetensi baca-tulis al-Qur'an IAIN Ambon, dan juga pada lampiran keputusan Rektor IAIN Ambon No 121 Tahun 2017 tentang penetapan standar kompetensi kenaikan dan 
kelulusan pembinaan baca-tulis al-Qur'an di Ma'had Al-Jami'ah IAIN Ambon yang menjadi acuan bagi Ma'had untuk memberikan syahadah atau ijazah sekurang-kurangnya memiliki hafalan al-Qur'an An-Nas sampai At-Thariq.

Sebagai mahasiswa PAI yang dipersiapkan sebagai calon guru, sangat disayangkan jika seorang guru PAl tidak mampu membaca alQur'an dengan baik dan tidak menghafal surah-surah pendek yaitu pada juz 30 sedikitpun, meskipun dengan alasan bukan merupakan lulusan dari pesantren. Sudah selayaknya bagi seorang Mahasiswa PAI sebagai calon guru hendaknya berusaha meluangkan waktunya untuk belajar al-Qur'an hingga menghafalkannya meskipun banyak tugas-tugas mata kuliah yang lainnya yang harus diselesaikan.

Mahasiswa yang berusaha untuk meluangkan waktunya untuk belajar baca-tulis Qur'an bahkan hingga berusaha menghafal beberapa surah dalam al-Qur'an mereka akan terlatih untuk meningkatkan daya ingat pada otak mereka, memanajemen waktu dengan baik, melatih mereka untuk tetap fokus dalam menghafal ayat demi ayat pada alQur'an, sehingga hal tersebut juga dapat memudahkan mereka dalam memahami mata kuliah yang mereka dapatkan dalam perkuliahan, sehingga dapat meningkatkan hasil belajar yang akan mereka peroleh di akhir semester.

\section{Teori Menghafal Al-Qur'an}

a) Pengertian Menghafal al-Qur'an

Secara etimologi menghafal dalam bahasa arab biasa diungkapkan dengan kata kerja حفظ yang berarti menjaga, memelihara dan melindungi. Masdar dari kata حفظ adalah حفظ yang diartikan sebagai "situasi jiwa yang telah siap untuk memahami sesuatu yang diingat, keadaan jiwa untuk mempertahankan hafalan dari lupa, dan usaha yang sungguhsungguh (al-muraja'ah) agar tidak hilang sesuatu yang telah dihafal" (ArRaghib Al-Asfahani, 2010). Sedangkan dalam Kamus Besar Bahasa 
Indonesia disebutkan bahwa menghafal berasal dari kata hafal yang berarti telah masuk di ingatan, dapat mengucapkan diluar kepala tanpa melihat buku atau catatan lain. Kemudian mendapat awalan me- sehingga menjadi menghafal yang Terjemahannya berusaha meresapkan ke pikiran agar selalu ingat (Desi Anwar, 2003).

Secara terminologi, ada beberapa pengertian menghafal menurut para ahli, diantaranya:

1) Cece Abdulwaly, menghafal adalah usaha yang dilakukan oleh seseorang untuk meresapkan suatu pelajaran tertentu ke dalam pikiran agar selalu ingat untuk kemudian terus-terus dijaga, dipelihara dan dilindungi agar tidak terlupakan (Cece Abdulwaly, 2019).

2) Mahmud, menghafal adalah kumpulan reaksi elektrokimia rumit yang diaktifkan melalui berbagai saluran indrawi yang disimpan dalam jaringan saraf yang sangat rumit di seluruh bagian otak( Mahmud, 2010).

3) Baharuddin, menghafal adalah menanamkan asosiasi dalam jiwa (Baharuddin, 2010).

Berdasarkan hasil uraian di atas dapat dikatakan bahwa menghafal adalah usaha yang dilakukan untuk memasukkan suatu materi ke dalam Ingatan, yang kemudian dijaga materi tersebut agar tidak dilupakan dari ingatannya, sehingga dapat dimunculkan kapan dan dimana saja ketika dibutuhkan. Secara etimologi al-Qur'an merupakan masdar dari kata qara'a yang berarti bacaan (Syukron Maksum dan Wahidi, 2013).

Secara terminologi al-Qur'an adalah firman Allah yang berfungsi sebagai mukjizat yang diturunkan kepada Nabi Muhammad SAW yang tertulis dalam mushaf-mushaf, yang diriwayatkan secara mutawatir, dan membacanya adalah ibadah (M. Nor Ichwan, 2001).

Menghafal al-Qur'an adalah "suatu proses mengulang-ulang bacaan al-Qur'an baik dengan cara membaca maupun dengan cara mendengar sehingga bacaan tersebut dapat melekat pada ingatan dan 
dapat diucapkan atau diulang tanpa melihat mushaf al-Qur'an" (Dina Fitriani, 2016).

Menghafal al-Qur'an adalah "suatu aktifitas menyimpan dan menjaga al-Qur'an dalam diri seseorang dengan sungguh-sungguh sebagai upaya untuk melestarikannya melalui kegiatan membaca maupun mendengar" (Amar Ma'ruf, 2019). Menghafal al-Qur'an juga merupakan proses mengingat, dimana seluruh materi ayat (rincian bagian-bagiannya waqaf dan lain sebagainya) harus diingat secara sempurna (Wiwi Alawiyah Wahid, 2014).

Dengan demikian dapat dikatakan bahwa menghafal al-Qur'an adalah upaya memasukkan ayat-ayat al-Qur'an ke dalam ingatan seseorang dengan adanya motivasi atau dorongan untuk menghafalnya baik dengan cara membaca ataupun mendengar, yang dilakukan secara berulang-ulang agar hafalan tersebut dapat diingat dan diulang tanpa melihat mushaf al-Qur'an.

\section{b) Hukum Menghafal al-Qur'an}

AI-Qur'an adalah kitab suci yang diturunkan Allah SWT kepada Rasulullah SAW melalui perantara Malaikat Jibril yang menjadi pedoman hidup bagi setiap umat manusia, karena dengan mengikuti petunjuk alQur'an maka manusia dapat keluar dari kegelapan menuju cahaya yang terang-benderang dengan izin Allah SWT.

Adapun pendapat Ulama mengenai hukum menghafal al-Qur'an yaitu:

1) Syaikh Ibnu Baz mengatakan, "menghafal al-Qur'an adalah mustahab (sunnah)” (Fatawa Nurun ‘alad Darbi, 89906). Namun yang rajih insya Allah, menghafal al-Qur'an adalah fardhu kifayah, wajib di antara kaum Muslimin ada yang menghafalkan alQur'an, jika tidak ada sama sekali maka mereka berdosa (Yulian Purnama, 2020).

2) Imam Jalaluddin As-Suyuthi berkata "Ketahuilah bahwa menghafal alQur'an merupakan fardu 'ain bagi umat Islam agar kemutawatirannya 
tidak terputus dan tidak tersentuh pergantian atau penyimpangan. Sementara menyelenggarakan pengajaran al-Qur'an merupakan fardu kifayah dan merupakan amal taqarrub yang paling baik (Abdurrahman An-Nahlawi, 2004).

Berdasarkan penjelasan para ulama di atas dapat dikatakan bahwa menghafal al-Qur'an secara keseluruhan hukumnya fardu kifayah sedangkan menghafal sebagiannya seperti surah Al-Fatihah adalah fardu ain mengingat shalat seseorang tidaklah sah ketika tidak membaca surah ini.

\section{c) Metode Menghafal al-Qur'an}

Setiap orang memiliki perbedaan metode dalam menghafal alQur'an yang digunakan untuk memudahkan dirinya. Berikut merupakan beberapa metode dalam menghafal al-Qur'an yang sering digunakan:

\section{1) Metode Mu'aaradah}

Yaitu murid dan murid yang lain membaca saling bergantian. Penghafal hanya memerlukan keseriusan dalam mendengarkan ayat alQur'an yang akan dihafalkan yang dibacakan oleh orang lain. Adapun jika kesulitan untuk mencari orang untuk diajak menggunakan metode ini, penghafal masih bisa menggunakan murottal al-Qur'an melalui kasetkaset tilawatul Qur'an (Abdul Aziz Abdul Rauf, 2004).

\section{2) Metode Talaqqi}

Metode talaqqi dapat disebut juga musyafahah, yaitu pengajaran al-Qur'an secara lisan. Bentuknya adalah guru membaca ayat yang dihafal kemudian murid membaca seperti bacaan guru, sehingga kekeliruan dan kesalahan hampir tidak terjadi. Salah satu hikmah pengajaran dengan metode talaqqi adalah terhindarnya murid dari kesalahan dalam membaca, selain itu murid juga akan menerima secara langsung pelajaran-pelajaran dari gurunya, pelajaran itu antara lain ayatayat yang mutasyabihat, cara-cara mengucapkan huruf-huruf yang benar, hukum-hukum tajwid dalam membaca al-Qur'an, selain itu juga terdapat penjelasan kandungan ayat (Farid Wajdi, 2008). 
3) Metode Bi Al-Nazhar

Yaitu membaca dengan cermat ayat-ayat al-Qur'an yang akan dihafal dengan melihat mushaf secara berulang-ulang. Proses $\mathrm{Bi}$ alNadzar ini hendaknya dilakukan sebanyak mungkin atau empat puluh satu kali seperti yang biasa dilakukan oleh para ulama terdahulu. Hal ini dilakukan untuk memperoleh gambaran menyeluruh tentang lafaz maupun urutan ayat-ayatnya (Sa'dulloh, 2013).

4) Metode Kitabah

Yaitu orang yang menghafal terlebih dahulu menulis ayat-ayat yang akan dihafalnya kemudian ayat-ayat tersebut dibacanya sampai lancar dan benar bacaannya, lalu dihafal. Aspek menulis juga akan sangat membantu dalam mempercepat terbentuknya pula hafalan dalam bayangannya (Amar Ma'ruf, 2019).

5) Metode Muraja'ah

Yaitu mengulangi atau membaca kembali ayat al-Qur'an yang sudah dihafal. Metode ini dapat dilakukan secara sendiri dan juga bisa bersama orang lain. Melakukan pengulangan bersama orang lain merupakan kebutuhan yang sangat pokok untuk mencapai kesuksesan dalam menghafal al-Qur'an. Teknik pelaksanaanya dapat diadakan perjanjian terlebih dahulu, antara tempat dan waktu pelaksanaan serta banyaknya ayat yang akan di murojaah (Abdul Aziz Abdul Rauf, 2004).

\section{Hasil belajar}

\section{a) Pengertian Hasil belajar}

Secara etimologi hasil belajar terdiri dari dua kata yaitu hasil dan belajar. Dalam Kamus Besar Bahasa Indonesia hasil memiliki arti sesuatu yang diadakan oleh usaha. Sedangkan belajar adalah perubahan tingkah laku atau tanggapan yang disebabkan oleh pengalaman (Tim Penyusun Pusat Bahasa, 2007).

Secara terminologi, ada beberapa pendapat para ahli dalam bidang pendidikan yang mendefinisikan hasil belajar adalah sebagai berikut: 
1) Burhanuddin Dkk, Hasil belajar adalah perolehan atau taraf kemampuan yang telah dicapai peserta didik (Burhanuddin, 2019).

2) E. Mulyasa, hasil belajar adalah hasil yang diperoleh seseorang setelah menempuh kegiatan belajar (E. Mulyasa, 2013).

3) Hasil belajar adalah kemampuan yang dimiliki, baik bersifat pengetahuan (kognitif), sikap (afektif) maupun keterampilan (psikomotorik) yang semuanya ini melalui proses belajar mengajar ( $\mathrm{M}$. Yusuf Mappeasse, 2009).

Berdasarkan hasil uraian yang dikemukakan para pakar pendidikan maka dapat dikatakan bahwa hasil belajar adalah hasil yang diperoleh peserta didik setelah mengikuti proses pembelajaran dalam waktu yang telah ditentukan lembaga pendidikan yang kemudian diwujudkan dalam bentuk angka, huruf maupun pernyataan.

\section{b) Faktor Yang Mempengaruhi Hasil belajar}

Hakikatnya setiap individu memiliki kemampuan yang berbedabeda, sehingga hasil belajar yang diperoleh setiap peserta didik tentunya berbeda-beda pula. Secara garis besar ada dua faktor yang mempengaruhi hasil belajar pada peserta didik yaitu faktor internal dan faktor eksternal (Ahmad Susanto, 2013).

1) Faktor internal adalah faktor yang berasal dari dalam diri peserta didik sehingga berpengaruh terhadap kemampuan belajarnya. Faktor internal ini meliput: kecerdasan, minat dan perhatian, motivasi belajar, ketekunan, sikap, kebiasaan belajar, serta kondisi fisik dan kesehatan.

2) Faktor eksternal adalah faktor yang berasal dari luar diri peserta didik, sehingga dapat mempengaruhi hasil belajarnya. Faktor eksternal ini meliputi: keluarga, sekolah, dan masyarakat

\section{c) Aspek Hasil belajar}

Usaha memudahkan memahami dan mengukur perubahan perilaku maka perilaku kejiwaan manusia sebagai hasil belajar menurut Benjamin S. Bloom dapat dikelompokkan ke dalam tiga domain yaitu kognitif, afektif, dan psikomotorik (Amar Ma'ruf, 2019. 
1) Aspek kognitif

Ranah kognitif adalah ranah yang mengacu pada kegiatan mental (otak). Adapun tingkatan pada ranah kognitif meliputi:

\begin{tabular}{|c|c|c|}
\hline LAMA & & REVISI \\
\hline Pengetahuan & C1 & Mengingat \\
Pemahaman & C2 & Memahami \\
Aplikasi & C3 & Mengaplikasikan \\
Analisis & C4 & Menganalisis \\
Sintesis & C5 & Mengevaluasi \\
Evaluasi & C6 & Mencipta \\
\hline
\end{tabular}

\section{2) Aspek Afektif}

Ranah afektif adalah ranah yang berkaitan dengan sikap dan nilai. Adapun tingkatan ranah afektif meliputi: A1 (Menerima), A2 (Merespon), A3 (Menghargai), A4 (Mengorganisasikan), A5 (Karakterisasi).

3) Aspek Psikomotorik

Ranah psikomotorik adalah ranah yang berkaitan dengan keterampilan. Adapun tingkatan ranah psikomotorik meliputi: P1 (Meniru), P2 (Manipulasi), P3 (Presisi), P4 (Artikulasi), P5 (Naturalisasi).

\section{METODE}

Penelitian ini adalah deskriptif kuantitatif yaitu suatu metode penelitian yang ditujukan untuk menggambarkan fenomena-fenomena yang ada, yang berlangsung pada saat ini maupun yang telah lampau (Nana Syaodih, 2009). Penggunaan jenis penelitian deskriptif kuantitatif oleh peneliti bertujuan untuk mengukur pengaruh menghafal al-Qur'an terhadap hasil belajar Mahasiswa IAIN Ambon Program Studi Pendidikan Agama Islam Angkatan 2017-2018.

Adapun teknik pengambilan sampel yang digunakan oleh peneliti adalah purposive sampling dengan alasan yaitu setiap individu yang 
terdapat dalam populasi tidak memiliki peluang yang sama untuk dijadikan sebagai sampel sehingga peneliti harus memilih individu yang cocok untuk dijadikan sebagai sampel yang sesuai dengan tujuan dan kebutuhan dalam melakukan penelitian yaitu mahasiswa yang memiliki hafalan minimal 1 juz dan maksimal 3 juz, dengan jumlah yang diteliti 33 mahasiswa.

Instrumen yang digunakan peneliti dalam melakukan penelitian ini adalah Observasi (Observation), Angket (Kuesioner) Angket (Kuesioner) dan Dokumentasi (Documentation). Dokumentasi adalah daftar yang berisikan patokan-patokan atau panduan dalam menelusuri sebuah dokumentasi (Purwanto, 2012). Dokumen merupakan catatan peristiwa yang sudah berlalu. Dokumen bisa berbentuk tulisan, gambar, atau karyakarya monumental dari seseorang (Sugiyono, 2017). Patokan peneliti dalam menelusuri dokumentasi ini adalah hasil belajar yang diambil dari dokumen KHS (IP semester 3 untuk angkatan 2018 dan IP semester 5 untuk angkatan 2017) mahasiswa yang menghafal al-Qur'an minimal 1 juz.

Untuk keperluan menganalisa data dalam penelitian ini, peneliti menggunakan teknik analisis yang sesuai dengan sifat dan jenis data yang ada. Adapun teknik analisis data yang peneliti gunakan adalah sebagai berikut:

1. Untuk data yang bersifat kualitatif digunakan analisa reflektif thinking yaitu dengan mengkombinasikan cara berfikir deduktif dan cara berfikir induktif (W. Gulo, 2000).

2. Untuk data yang bersifat kuantitatif, peneliti menggunakan analisis statistik yaitu teknik analisis regresi linier sederhana.

\section{HASIL}

\section{Aktivitas Mahasiswa Dalam Menghafal al-Qur'an}

Tabel 1. Tekad Mahasiswa Untuk Menjadi Hafizh/Hafizhah Qur'an

\begin{tabular}{|c|l|r|r|}
\hline \multirow{2}{*}{1} & Sangat Setuju & 12 & $36.37 \%$ \\
\cline { 2 - 4 } & Setuju & 21 & $63,63 \%$ \\
\hline
\end{tabular}




\begin{tabular}{|l|c|c|}
\hline Kurang Setuju & 0 & $0 \%$ \\
\cline { 2 - 3 } Tidak Setuju & 0 & $0 \%$ \\
\hline Sangat Tidak Setuju & 0 & $0 \%$ \\
\hline Total & 33 & $100 \%$ \\
\hline
\end{tabular}

Sumber: Data diolah 2020

Berdasarkan tabel di atas terlihat 12 responden atau 36,37\% menjawab sangat setuju, 21 responden atau 63,63\% menjawab setuju, dan tidak satupun responden atau 0 \% menjawab kurang setuju, tidak setuju dan sangat tidak setuju. Dari pernyataan ini menunjukkan bahwa seluruh responden memiliki tekad untuk menjadi seorang penghafal alQur'an. Hal tersebut dapat dilihat pada grafik pengisian angket sebagai berikut:

Tabel 2. Mahasiswa Menghafal Qur'an Agar Dipuji Teman

\begin{tabular}{|l|l|c|c|}
\hline \multirow{3}{*}{2} & Sangat Setuju & 0 & $0 \%$ \\
\cline { 2 - 4 } & Setuju & 0 & $0 \%$ \\
\cline { 2 - 4 } & Kurang Setuju & 2 & $6,06 \%$ \\
\cline { 2 - 4 } & Tidak Setuju & 6 & $18,19 \%$ \\
\cline { 2 - 4 } & Sangat Tidak Setuju & 25 & $75,75 \%$ \\
\cline { 2 - 4 } & Total & 33 & $100 \%$ \\
\hline
\end{tabular}

Sumber: Data diolah 2020

Berdasarkan tabel di atas terlihat 25 responden atau 75,75\% menjawab sangat tidak setuju, 6 responden atau 18,19\% menjawab tidak setuju, 2 responden atau 6,06 \% menjawab kurang setuju, dan tidak satupun responden atau $0 \%$ menjawab setuju dan sangat setuju. Dari pernyataan ini menunjukkan bahwa sebagian besar mahasiswa menghafal al-Qur'an bukan untuk mendapatkan pujian melainkan pahala yang mereka harapkan. Hal tersebut dapat dilihat pada grafik pengisian angket sebagai berikut:

Tabel 3. Mahasiswa Menghafal al-Qur'an hanya untuk mendapat ijazah dari Ma'had

\begin{tabular}{|c|l|c|c|}
\hline \multirow{3}{*}{3} & Sangat Setuju & 0 & $0 \%$ \\
\cline { 2 - 4 } & Setuju & 0 & $0 \%$ \\
\cline { 2 - 4 } & Kurang Setuju & 0 & $0 \%$ \\
\cline { 2 - 4 } & Tidak Setuju & 12 & $36,37 \%$ \\
\cline { 2 - 4 } & Sangat Tidak Setuju & 21 & $63,63 \%$ \\
\hline
\end{tabular}




\section{Sumber: Data diolah 2020}

\begin{tabular}{|l|c|c|}
\hline Total & 33 & $100 \%$ \\
\hline
\end{tabular}

Berdasarkan tabel di atas terlihat 21 responden atau 63,63\% menjawab sangat tidak setuju, 12 responden atau 36,37 \% menjawab tidak setuju, dan tidak satupun responden atau 0 \% menjawab kurang setuju, setuju dan sangat setuju. Dari pernyataan ini menunjukkan bahwa sebagian besar mahasiswa yang memiliki hafalan al-Qur'an 1 juz atau lebih telah memiliki niat yang ikhlas dalam menghafal al-Qur'an. Hal tersebut dapat dilihat pada grafik pengisian angket sebagai berikut:

Tabel 4. Motivasi Menghafal al-Qur'an dari teman

\begin{tabular}{|c|c|c|c|}
\hline \multirow{3}{*}{4} & Sangat Setuju & 19 & $57,57 \%$ \\
\cline { 2 - 4 } & Setuju & 9 & $27,28 \%$ \\
\cline { 2 - 4 } & Kurang Setuju & 5 & $15,15 \%$ \\
\cline { 2 - 4 } & Tidak Setuju & 0 & $0 \%$ \\
\cline { 2 - 4 } & Sangat Tidak Setuju & 0 & $0 \%$ \\
\cline { 2 - 4 } & Total & 33 & $100 \%$ \\
\hline
\end{tabular}

Sumber: Data diolah 2020

Berdasarkan tabel di atas terlihat 19 responden atau 57,57\% menjawab sangat setuju, 9 responden atau 27,28 \% menjawab setuju, 5 responden atau 15,15\% menjawab kurang setuju, dan tidak satupun responden atau $0 \%$ menjawab tidak setuju dan sangat tidak setuju. Dari pernyataan ini menunjukkan bahwa sebagian besar mahasiswa menghafalkan al-Qur'an termotivasi oleh temannya yang juga menghafal al-Qur'an. Hal tersebut dapat dilihat pada grafik pengisian angket sebagai berikut:

Tabel 5. Perhatian Ustadz/Ustadzah dalam memotivasi Mahasiswa Untuk Menghafal al-Qur'an

\begin{tabular}{|c|l|c|c|}
\hline \multirow{3}{*}{5} & Sangat Setuju & 14 & $42,42 \%$ \\
\cline { 2 - 4 } & Setuju & 19 & $57,58 \%$ \\
\cline { 2 - 4 } & Kurang Setuju & 0 & $0 \%$ \\
\cline { 2 - 4 } & Tidak Setuju & 0 & $0 \%$ \\
\cline { 2 - 4 } & Sangat Tidak Setuju & 0 & $0 \%$ \\
\cline { 2 - 4 } & Total & 33 & $100 \%$ \\
\hline
\end{tabular}

Sumber: Data diolah 2020

Berdasarkan tabel di atas terlihat 14 responden atau $42,42 \%$ menjawab sangat setuju, 19 responden atau $57,58 \%$ menjawab setuju, 
dan tidak satupun responden atau $0 \%$ menjawab kurang setuju, tidak setuju dan sangat tidak setuju. Dari pernyataan ini menunjukkan bahwa Motivasi yang diberikan ustadz/ustadzah pengajar al-Qur'an di ma'had kepada mahasiswa dalam menghafal al-Qur'an memiliki pengaruh yang besar. Hal tersebut dapat dilihat pada grafik pengisian angket sebagai berikut:

Tabel 6. Menghafal al-Qur'an Menggunakan Mushaf

\begin{tabular}{|c|l|c|c|}
\hline \multirow{6}{*}{6} & Sangat Setuju & 17 & $51,51 \%$ \\
\cline { 2 - 4 } & Setuju & 16 & $48,49 \%$ \\
\cline { 2 - 4 } & Kurang Setuju & 0 & $0 \%$ \\
\cline { 2 - 4 } & Tidak Setuju & 0 & $0 \%$ \\
\cline { 2 - 4 } & Sangat Tidak Setuju & 0 & $0 \%$ \\
\cline { 2 - 4 } & Total & 33 & $100 \%$ \\
\hline
\end{tabular}

Sumber: Data diolah 2020

Berdasarkan tabel di atas terlihat 17 responden atau 51,51\% menjawab sangat setuju, 16 responden atau 48,49 \% menjawab setuju, dan tidak satupun responden atau $0 \%$ menjawab kurang setuju, tidak setuju dan sangat tidak setuju. Dari pernyataan ini menunjukkan bahwa sebagian besar mahasiswa menghafal al-Qur'an menggunakan mushaf. Hal tersebut dapat dilihat pada grafik pengisian angket sebagai berikut:

Tabel 7. Membaca ayat Yg hendak Dihafal Minimal 3 kali

\begin{tabular}{|c|l|c|c|}
\hline \multirow{4}{*}{7} & Sangat Setuju & 21 & $63,64 \%$ \\
\cline { 2 - 4 } & Setuju & 11 & $33,33 \%$ \\
\cline { 2 - 4 } & Kurang Setuju & 1 & $3,03 \%$ \\
\cline { 2 - 4 } & Tidak Setuju & 0 & $0 \%$ \\
\cline { 2 - 4 } & Sangat Tidak Setuju & 0 & $0 \%$ \\
\cline { 2 - 4 } & Total & 33 & $100 \%$ \\
\hline
\end{tabular}

Sumber: Data diolah 2020

Berdasarkan tabel di atas terlihat 21 responden atau 63,64\% menjawab sangat setuju, 11 responden atau 33,33 \% menjawab setuju, 1 responden atau 3,03 \% menjawab kurang setuju, dan tidak satupun responden atau $0 \%$ menjawab tidak setuju dan sangat tidak setuju. Dari pernyataan ini menunjukkan bahwa sebagian mahasiswa sebelum menghafal al-Qur'an mereka membacanya minimal 3 kali barulah kemudian mereka mulai menghafalnya. Hal tersebut dapat dilihat pada grafik pengisian angket sebagai berikut: 
Tabel 8. Membaca Ayat al-Qur'an Dengan Suara Yang Jelas Yang Hendak Dihafal

\begin{tabular}{|c|l|c|c|}
\hline \multicolumn{1}{|c|}{} & Sangat Setuju & 19 & $57,58 \%$ \\
\cline { 2 - 4 } 8 & Setuju & 13 & $39,39 \%$ \\
\cline { 2 - 4 } 8 & Kurang Setuju & 1 & $3,03 \%$ \\
\cline { 2 - 4 } & Tidak Setuju & 0 & $0 \%$ \\
\cline { 2 - 4 } & Sangat Tidak Setuju & 0 & $0 \%$ \\
\cline { 2 - 4 } & Total & 33 & $100 \%$ \\
\hline
\end{tabular}

Sumber: Data diolah 2020

Berdasarkan tabel di atas terlihat 19 responden atau 57,58\% menjawab sangat setuju, 13 responden atau 39,39 \% menjawab setuju, 1 responden atau 3,03 \% menjawab kurang setuju, dan tidak satupun responden menjawab tidak setuju, dan sangat tidak setuju. Dari pernyataan ini menunjukkan bahwa sebagian besar mahasiswa membaca ayat al-Qur'an dengan suara yang jelas yang hendak dihafal. Hal tersebut dapat dilihat pada grafik pengisian angket sebagai berikut:

Tabel 9. Memiliki Orang Yang Dipercayai Untuk Menyimakkan Hafalan Yang Telah Dihafal

\begin{tabular}{|c|l|c|c|}
\hline \multirow{3}{*}{9} & Sangat Setuju & 15 & $45,46 \%$ \\
\cline { 2 - 4 } & Setuju & 18 & $54,54 \%$ \\
\cline { 2 - 4 } & Kurang Setuju & 0 & $0 \%$ \\
\cline { 2 - 4 } & Tidak Setuju & 0 & $0 \%$ \\
\cline { 2 - 4 } & Sangat Tidak Setuju & 0 & $0 \%$ \\
\hline \multirow{2}{*}{ Total } & 33 & $100 \%$ \\
\hline
\end{tabular}

Sumber: Data diolah 2020

Berdasarkan tabel di atas terlihat 15 responden atau 45,46\% menjawab sangat setuju, 18 responden atau 54,54 \% menjawab setuju, dan tidak satupun responden atau $0 \%$ menjawab kurang setuju, tidak setuju dan sangat tidak setuju. Dari pernyataan ini menunjukkan bahwa sebagian besar mahasiswa yang menghafal al-Qur'an memiliki orang yang dipercayai untuk menyimakkan hafalan yang telah dihafal. Hal tersebut dapat dilihat pada grafik pengisian angket sebagai berikut:

Tabel 10. Sering Mendengar Musik Dibandingkan Mendengar Murottal Di HP.

\begin{tabular}{|l|l|c|c|}
\hline \multirow{2}{*}{10} & Sangat Setuju & 0 & $0 \%$ \\
\cline { 2 - 3 } & Setuju & 2 & $6,06 \%$ \\
\hline
\end{tabular}




\begin{tabular}{|l|c|c|}
\hline Kurang Setuju & 11 & $33,33 \%$ \\
\hline Tidak Setuju & 3 & $9,10 \%$ \\
\hline Sangat Tidak Setuju & 17 & $51,51 \%$ \\
\hline Total & 33 & $100 \%$ \\
\hline
\end{tabular}

Sumber: Data diolah 2020

Berdasarkan tabel di atas terlihat 17 responden atau 51,51\% menjawab sangat tidak setuju, 3 responden atau 9,10 \% menjawab tidak setuju, yang menunjukkan bahwa sebanyak 60,61 \% mahasiswa yang memiliki hafalan al-Qur'an 1 juz atau lebih mereka lebih suka mendengarkan murotal yang dapat membantu mereka untuk memperkuat hafalan mereka dibandingkan harus mendengarkan musik, 11 responden atau 33,33 \% menjawab kurang setuju, hal ini menunjukkan bahwa mereka lebih banyak mendengarkan murotal dibandingkan dengan musik, hanya saja sesekali mereka masih mendengarkan musik, 2 responden atau 6,06 \% mereka lebih cenderung mendengarkan musik dibandingkan murotal menggunakan HP mereka, dan tidak satupun atau $0 \%$ yang menjawab sangat setuju. Hal tersebut dapat dilihat pada grafik pengisian angket sebagai berikut:

Tabel 11. Mendengar Murottal Untuk Memperkuat Hafalan Yang Telah Dihafal

\begin{tabular}{|l|l|c|c|}
\hline \multicolumn{1}{|c|}{} & Sangat Setuju & 21 & $63,63 \%$ \\
\cline { 2 - 4 } & Setuju & 11 & $33,34 \%$ \\
\cline { 2 - 4 } 11 & Kurang Setuju & 1 & $3,03 \%$ \\
\cline { 2 - 4 } & Tidak Setuju & 0 & $0 \%$ \\
\cline { 2 - 4 } & Sangat Tidak Setuju & 0 & $0 \%$ \\
\hline \multirow{2}{*}{ Total } & 33 & $100 \%$ \\
\hline
\end{tabular}

Sumber: Data diolah 2020

Berdasarkan tabel di atas terlihat 21 responden atau 63,63\% menjawab sangat setuju, 11 responden atau 33,34 \% menjawab setuju, 1 responden atau 3,03 \% menjawab kurang setuju, dan tidak satupun responden menjawab tidak setuju, dan sangat tidak setuju. Dari pernyataan ini menunjukkan bahwa sebagian besar mahasiswa mendengar murottal untuk memperkuat hafalan yang telah dihafal, dan sebagian yang lain sangat jarang mendengarkan murotal untuk 
memperkuat hafalannya melainkan menggunakan metode yang lain. Hal tersebut dapat dilihat pada grafik pengisian angket sebagai berikut:

Tabel 12. Mahasiswa Dengan Senang Hati Menyimak Setoran Hafalan Temannya

\begin{tabular}{|l|l|c|c|}
\hline \multirow{3}{*}{12} & Sangat Setuju & 17 & $51,51 \%$ \\
\cline { 2 - 4 } & Setuju & 3 & $9,10 \%$ \\
\cline { 2 - 4 } & Kurang Setuju & 10 & $30,30 \%$ \\
\cline { 2 - 4 } & Tidak Setuju & 2 & $6,06 \%$ \\
\cline { 2 - 4 } & Sangat Tidak Setuju & 1 & $3,03 \%$ \\
\cline { 2 - 4 } & Total & 33 & $100 \%$ \\
\hline
\end{tabular}

Sumber: Data diolah 2020

Berdasarkan tabel di atas terlihat 17 responden atau 51,51\% menjawab sangat setuju, 3 responden atau 9,10 \% menjawab setuju, 10 responden atau 30,30 \% menjawab kurang setuju, 2 responden atau 6,06 \% menjawab tidak setuju, dan 1 responden atau 3,03 \% sangat tidak setuju. Dari pernyataan ini menunjukkan bahwa sebagian besar mahasiswa dengan senang hati menyimak setoran hafalan temannya, dan ada beberapa mahasiswa yang kadang mereka merasa kurang nyaman ketika diminta temannya untuk menyimak hafalan yang telah ia peroleh, dan sebagian yang lain mereka merasa tidak nyaman ketika diminta temannya untuk menyimak hafalan yang telah diperoleh. Hal tersebut dapat dilihat pada grafik pengisian angket sebagai berikut:

Tabel 13 Mengulang 2 Ayat Yang Telah Dihafal Sebelum Lanjut Ke Ayat Berikutnya

\begin{tabular}{|l|l|c|c|}
\hline \multirow{8}{*}{13} & Sangat Setuju & 13 & $39,39 \%$ \\
\cline { 2 - 4 } & Setuju & 19 & $57,58 \%$ \\
\cline { 2 - 4 } & Kurang Setuju & 1 & $3,03 \%$ \\
\cline { 2 - 4 } & Tidak Setuju & 0 & $0 \%$ \\
\cline { 2 - 4 } & Sangat Tidak Setuju & 0 & $0 \%$ \\
\hline \multirow{2}{*}{ Total } & 33 & $100 \%$ \\
\hline
\end{tabular}

Sumber: Data diolah 2020

Berdasarkan tabel di atas terlihat 13 responden atau 39,39\% menjawab sangat setuju, 19 responden atau 57,58 \% menjawab setuju, 1 responden atau 3,03 \% menjawab kurang setuju, dan tidak satupun responden menjawab tidak setuju, dan sangat tidak setuju. Dari pernyataan ini menunjukkan bahwa sebagian besar mahasiswa 
mengulang 2 ayat yang telah dihafal sebelum lanjut ke ayat berikutnya. Hal tersebut dapat dilihat pada grafik pengisian angket sebagai berikut:

Tabel 14. Mengulang Ayat Yang Telah Dihafal Ketika Shalat Fardhu

\begin{tabular}{|l|l|c|c|}
\hline \multirow{3}{*}{14} & Sangat Setuju & 19 & $57,58 \%$ \\
\cline { 2 - 4 } & Setuju & 12 & $36,36 \%$ \\
\cline { 2 - 4 } & Kurang Setuju & 2 & $6,06 \%$ \\
\cline { 2 - 4 } & Tidak Setuju & 0 & $0 \%$ \\
\cline { 2 - 4 } & Sangat Tidak Setuju & 0 & $0 \%$ \\
\hline \multirow{2}{*}{ Total } & 33 & $100 \%$ \\
\hline
\end{tabular}

Sumber: Data diolah 2020

Berdasarkan tabel di atas terlihat 19 responden atau 57,58 \% menjawab sangat setuju, 12 responden atau 36,36 \% menjawab setuju, 2 responden atau 6,06 \% menjawab kurang setuju, dan tidak satupun responden menjawab tidak setuju, dan sangat tidak setuju. Dari pernyataan ini menunjukkan bahwa sebagian besar mahasiswa mengulang ayat yang telah dihafal ketika shalat fardhu. Hal tersebut dapat dilihat pada grafik pengisian angket sebagai berikut:

Tabel 15. Mengulang Ayat Yang Telah Dihafal Setiap Hari

\begin{tabular}{|c|l|c|c|}
\hline \multirow{1}{*}{15} & Sangat Setuju & 11 & $33,33 \%$ \\
\cline { 2 - 4 } & Setuju & 14 & $42,43 \%$ \\
\cline { 2 - 4 } & Kurang Setuju & 7 & $21,21 \%$ \\
\cline { 2 - 4 } & Tidak Setuju & 1 & $3,03 \%$ \\
\cline { 2 - 4 } & Sangat Tidak Setuju & 0 & $0 \%$ \\
\hline \multirow{2}{*}{ Total } & 33 & $100 \%$ \\
\hline
\end{tabular}

Sumber: Data diolah 2020

Berdasarkan tabel di atas terlihat 11 responden atau 33,33\% menjawab sangat setuju, 14 responden atau 42,43 \% menjawab setuju, 7 responden atau 21,21 \% menjawab kurang setuju, 1 responden atau 3,03 $\%$ menjawab tidak setuju dan tidak satupun responden menjawab sangat tidak setuju. Dari pernyataan ini menunjukkan bahwa sebagian besar mahasiswa mengulang ayat yang telah dihafal setiap harinya, sebagian yang lain jarang untuk murajaah hafalan al-Qur'an yang telah dihafal, dan ada sebagian kecil yang hampir tidak pernah untuk murajaah hafalan yang telah ia peroleh. Hal tersebut dapat dilihat pada grafik pengisian angket sebagai berikut: 


\section{PEMBAHASAN}

Analisis data dilakukan oleh peneliti bertujuan untuk mengolah data yang telah terkumpul ketika melakukan penelitian, baik variabel $X$ (menghafal al-Qur'an) maupun variabel $Y$ (hasil belajar) dengan tujuan agar dapat mengetahui apakah hipotesis yang diajukan oleh peneliti diterima atau ditolak. Berikut ini langkah-langkah yang dilakukan oleh peneliti dalam pengujian hipotesis.

\section{Uji Regresi Linier Sederhana}

Uji regresi linier sederhana dilakukan bertujuan untuk mengetahui pengaruh menghafal al-Qur'an terhadap hasil belajar Mahasiswa. Berikut merupakan hasil uji regresi linier sederhana dengan menggunakan bantuan SPSS Versi 21.

Tabel 16. Hasil Uji Regresi Linier Sederhana

\section{Coefficients $^{\mathrm{a}}$}

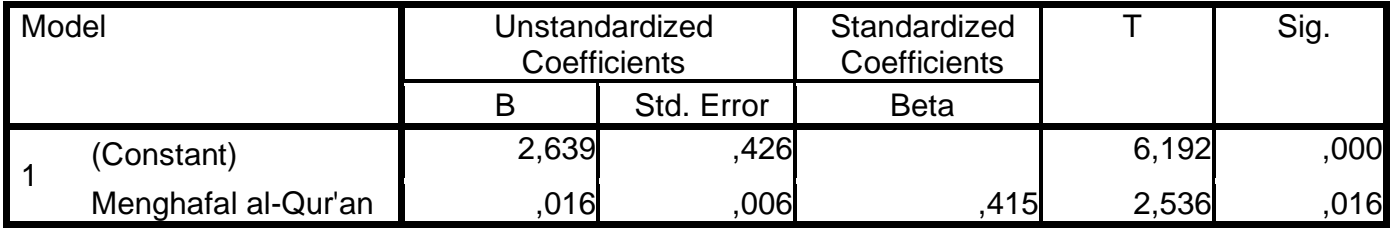

a. Dependent Variable: Hasil belajar

Sumber: Data diolah 2020

Berdasarkan tabel $4.18 \mathrm{uji}$ regresi linier sederhana tersebut diketahui nilai constant sebesar 2,639, sedangkan nilai menghafal alQur'an sebesar 0,016. Sehingga nilai partisipasinya dapat ditulis:

$$
\begin{aligned}
& Y=a+b X \\
& Y=2,639+0,016 X
\end{aligned}
$$

Hasil persamaan uji regresi linier sederhana tersebut dapat diartikan sebagai berikut:

$\mathrm{a}=$ konstanta sebesar 2,639 mengandung arti bahwa nilai konsisten dari variabel hasil belajar jika tidak dengan menghafal al-Qur'an (X) adalah sebesar 2,639. 
$\mathrm{b}=$ koefisien regresi $\mathrm{X}$ sebesar 0,016 menyatakan bahwa setiap penambahan 1\% nilai menghafal al-Qur'an, maka nilai hasil belajar bertambah 0,016.

Dengan demikian dapat dikatakan bahwa menghafal al-Qur'an (variabel X) berpengaruh terhadap hasil belajar mahasiswa (variabel Y).

\section{Uji Hipotesis}

Pengujian hipotesis dimaksudkan untuk mengetahui ada atau tidaknya pengaruh variabel bebas (menghafal al-qur'an) terhadap variabel terikat (hasil belajar siswa). Hasil hipotesis yang ditemukan dengan bantuan SPSS IBM 21 adalah sebagai berikut:

Tabel 17. Hasil Uji Hipotesis

\begin{tabular}{|c|c|c|c|c|c|}
\hline \multirow[t]{2}{*}{ Model } & \multicolumn{2}{|c|}{$\begin{array}{l}\text { Unstandardized } \\
\text { Coefficients }\end{array}$} & $\begin{array}{c}\text { Standardized } \\
\text { Coefficients } \\
\end{array}$ & \multirow[t]{2}{*}{$\mathrm{T}$} & \multirow[t]{2}{*}{ Sig. } \\
\hline & $\mathrm{B}$ & Std. Error & Beta & & \\
\hline (Constant) & 2,639 & ,426 & & 6,192 & ,000 \\
\hline Menghafal al-Qur'an & 016 &, 006 & ,415 & 2,536 &, 016 \\
\hline
\end{tabular}

a. Dependent Variable: Hasil belajar

Sumber: Data diolah 2020

Berdasarkan pada tabel 4.19, diketahui nilai thitung menghafal alQur'an 2,536 lebih besar dari nilai tabel yang telah ditetapkan sebesar 2,04 . Sedangkan nilai signifikansi $0,016<0,05$. Untuk mencari nilai tabel yaitu dengan menggunakan rumus:

Dk sisa $=\mathrm{N}-2$

$$
\begin{aligned}
& =33-2 \\
& =31
\end{aligned}
$$

Sehingga tabel: $0,05: 31=2,039$

Adapun kriteria dalam pengambilan keputusan uji hipotesis adalah sebagai berikut:

a. Jika nilai thitung $<$ tabel maka $\mathrm{H}_{\mathrm{a}}$ ditolak dan $\mathrm{H}_{\mathrm{o}}$ diterima, untuk hasil uji $\mathrm{t}$, jika nilai signifikan > 0,05 maka hal ini berarti tidak terdapat pengaruh antara menghafal al-Qur'an terhadap hasil belajar mahasiswa. Sebaliknya, 
b. Jika nilai thitung $>$ ttabel maka $\mathrm{H}_{\mathrm{o}}$ ditolak dan $\mathrm{H}_{\mathrm{a}}$ diterima, untuk hasil uji $\mathrm{t}$, jika nilai signifikan < 0,05 maka hal ini berarti terdapat pengaruh antara menghafal al-Qur'an terhadap hasil belajar mahasiswa.

Berdasarkan kriteria dalam pengambilan keputusan tersebut, maka dapat dikatakan bahwa $\mathrm{H}_{\mathrm{a}}$ diterima dan $\mathrm{H}_{\mathrm{o}}$ ditolak, yang mengandung arti bahwa menghafal al-Qur'an berpengaruh terhadap hasil belajar dan pengaruhnya bersifat linier.

\section{Nilai Koefisien Determinasi ( $R$ Square)}

Nilai Koefisien determinasi digunakan untuk mengetahui seberapa besar kontribusi yang diberikan variabel bebas (menghafal al-Qur'an) terhadap variabel terikat (hasil belajar). Adapun nilai koefisien determinasi adalah sebagai berikut:

Tabel 18. Nilai Koefisien Determinasi

Model Summary

\begin{tabular}{|l|r|r|r|r|}
\hline Model & $\mathrm{R}$ & $\mathrm{R}$ Square & $\begin{array}{c}\text { Adjusted R } \\
\text { Square }\end{array}$ & $\begin{array}{c}\text { Std. Error of the } \\
\text { Estimate }\end{array}$ \\
\hline 1 &, $415^{\mathrm{a}}$ &, 172 &, 145 &, 19149 \\
\hline
\end{tabular}

a. Predictors: (Constant), Menghafal al-Qur'an

Sumber: Data diolah 2020

Berdasarkan tabel 4.20 nilai koefisien determinasi diketahui nilai $r_{\text {hitung }}$ di atas sebesar 0,415. Dengan nilai koefisien determinasi ( $R$ Square) diperoleh sebesar 0,172, yang mengandung arti bahwa pengaruh variabel bebas (Menghafal al-Qur'an) terhadap variabel terikat (Hasil belajar) adalah sebesar $17,2 \%$ dan sisanya yaitu $82,8 \%$ dipengaruhi oleh faktor lain yang tidak diteliti dalam penelitian ini.

Dari hasil analisis data penelitian yang telah peneliti lakukan dengan bantuan aplikasi SPSS IBM 21 dengan menggunakan rumus regresi linier sederhana, maka diperoleh hasil bahwa variabel (X) Menghafal al-Qur'an memiliki pengaruh yang signifikan terhadap variabel (Y) Hasil belajar pada mahasiswa IAIN Ambon, Fakultas IImu Tarbiyah Dan Keguruan, Program Studi Pendidikan Agama Islam, yaitu diketahui nilai constant sebesar 2,639, sedangkan nilai menghafal al-Qur'an sebesar 0,016. Sehingga nilai partisipasinya dapat ditulis: 
$Y=a+b X$

$Y=2,639+0,016 X$

Hasil persamaan uji regresi linier sederhana tersebut dapat diartikan sebagai berikut:

$\mathrm{a}=$ konstanta sebesar 2,639 mengandung arti bahwa nilai konsisten dari variabel hasil belajar jika tidak ada menghafal al-Qur'an (X) adalah sebesar 2,639.

$\mathrm{b}=$ koefisien regresi $\mathrm{X}$ sebesar 0,016 menyatakan bahwa setiap penambahan $1 \%$ nilai menghafal al-Qur'an, maka nilai hasil belajar bertambah 0,016. Hal ini dibuktikan berdasarkan hasil uji t, yaitu nilai thitung menghafal al-Qur'an adalah $=2,639>$ nilai $t_{\text {tabel }}$ yang telah ditetapkan yaitu sebesar 2,039. Sedangkan nilai signifikansi 0,016<0,05. Jadi thitung lebih besar dari tabel maka dapat disimpulkan bahwa hipotesis nol $\left(\mathrm{H}_{\circ}\right)$ ditolak dan $\left(\mathrm{H}_{\mathrm{a}}\right)$ diterima, dengan kriteria pengambilan keputusan yaitu Jika nilai thitung < tabel maka $\mathrm{H}_{\mathrm{a}}$ ditolak dan $\mathrm{H}_{\mathrm{o}}$ diterima, untuk hasil uji $\mathrm{t}$, jika nilai signifikan > 0,05 maka hal ini berarti tidak terdapat pengaruh antara menghafal al-Qur'an terhadap hasil belajar mahasiswa. Sebaliknya, Jika nilai thitung $>$ tabel maka $\mathrm{H}_{\mathrm{o}}$ ditolak dan $\mathrm{H}_{\mathrm{a}}$ diterima, untuk hasil uji $\mathrm{t}$, jika nilai signifikan $<0,05$ maka hal ini berarti terdapat pengaruh antara menghafal al-Qur'an terhadap hasil belajar mahasiswa. Dengan menggunakan rumus untuk mencari nilai tabel yaitu :

Dk sisa $=\mathrm{N}-2$

$$
\begin{aligned}
& =33-2 \\
& =31
\end{aligned}
$$

Adapun perhitungan nilai koefisien determinasi diketahui nilai $r_{h i t u n g}$ diperoleh nilai sebesar 0,415 . Dengan nilai koefisien determinasi ( $R$ Square) yaitu sebesar 0,172, yang mengandung arti bahwa pengaruh variabel bebas (Menghafal al-Qur'an) terhadap variabel terikat (Hasil belajar) adalah sebesar $17,2 \%$. dan sisanya yaitu $82,8 \%$ dipengaruhi oleh faktor lain yang tidak diteliti dalam penelitian ini. 
Pengaruh positif yang ditimbulkan dari menghafal al-Qur'an tidak hanya bisa kita lihat berdasarkan hasil perhitungan statistika dengan menggunakan rumus regresi linier saja, melainkan dapat kita lihat berdasarkan kondisi yang nyata dilapangan. Berdasarkan hasil pengamatan peneliti, orang yang memiliki hafalan al-Qur'an minimal 1 juz rata-rata memiliki daya ingat yang cukup kuat, hal ini dikarenakan ketika melakukan kegiatan menghafal al-Qur'an maka secara tidak langsung mereka telah melatih diri mereka untuk konsentrasi, memanajemen waktu dengan baik, dan meningkatkan kemampuan mengingat yang dimilikinya, sehingga hal tersebut sangat membantu mereka dalam proses pembelajaran yang mereka lakukan di kelas, karena untuk memahami sebuah mata pelajaran maka dibutuhkan adalah konsentrasi, daya ingat yang baik, dan manajemen waktu yang baik agar bisa mengulangi mata pelajaran yang diterimanya di kampus. Kondisi yang nyata juga dapat kita lihat pada nilai hasil belajar semester yang dimiliki oleh mahasiswa yang peneliti jadikan sebagai responden yaitu berjumlah 33 orang mahasiswa semuanya memiliki nilai hasil belajar diatas 3.00 bahkan sebagian mahasiswa memiliki nilai yang sempurna yaitu mencapai 4.00.

Hal ini diraih disebabkan orang yang menghafal al-Qur'an dengan istiqamah dengan niat yang diikhlaskan hanya kepada Allah SWT. mampu menumbuhkan kecintaan mendalam kepada Allah SWT. Ketika rasa cinta sudah merasuk dan al-Qur'an selalu menjadi teman kehidupan, Allah akan mencintai hamba tersebut dengan memberikan kelebihan kepada hamba tersebut yang bermanfaat bagi dirinya.

Berdasarkan pendapat tersebut dapat disimpulkan bahwa keberhasilan meraih hasil belajar yang memuaskan dipengaruhi oleh kebiasaan, ketajaman kemampuan otak, dan semangat yang tinggi. Pengaruh yang diberikan tersebut berasal dari kebiasaan seseorang yang menghafal al-Qur'an secara terus-menerus (istiqomah). Ketajaman ingatan dan kebersihan intuisi muncul karena seorang penghafal AlQur'an selalu berupaya mencocokkan ayat-ayat yang dihafalnya dan 
membandingkan ayat-ayat tersebut ke porosnya, baik dari segi lafal (teks ayat) maupun dari segi pengertiannya (Ahsin Al-Hafidz W., 2005). Manfaat dari menghafal al-Qur'an salah satunya adalah kemudahan dalam memahami pelajaran di sekolah baik pelajaran agama maupun pelajaran umum (Lisya Chairani dan M. A. Subandi, 2010). sehingga apabila seseorang menghafal al-Qur'an secara terus-menerus (istiqamah) akan berdampak positif pada kemudahan proses belajar seseorang. Hal tersebut akan mempermudah seseorang untuk meraih keberhasilan belajar berupa hasil belajar yang memuaskan, sehingga dapat dikatakan bahwa hasil belajar akan meningkat apabila seorang penghafal al-Qur'an mampu istiqamah dalam hafalannya.

Hal ini sejalan dengan hasil penelitian yang dilakukan oleh Mustofa Kamal pada tahun 2017 dengan judul skripsi: Pengaruh Pelaksanaan Program Menghafal AI-Qur'an Terhadap Prestasi Belajar Siswa (Studi Kasus di MA Sunan Giri Wonosari Tegal Semampir Surabaya), yang menyatakan bahwa perbedaan hasil belajar siswa yang mengikuti program tahfidz al-Qur'an di SMP Muhammadiyah 9 Watukebo dapat dijelaskan bahwa mengalami peningkatan rata-rata hasil belajar siswa sebelum mengikuti program tahfidz dengan setelah mengikuti program tahfidz al-Qur'an. ${ }^{1}$ Hal ini disebabkan dari menghafal al-Qur'an, anak secara tidak langsung belajar mengasah kemampuan untuk menghafal dari yang dilihat dan dibaca. Dengan demikian siswa akan terbiasa menghafal sesuatu yang di baca, di lihat dan di dengar, hal ini juga mempengaruhi kecepatan otak anak dalam memproses mata pelajaran yang diterimanya.

\section{KESIMPULAN}

Dari pemaparan teori dan hasil penelitian di lapangan, maka peneliti dapat menyimpulkan bahwa terdapat pengaruh menghafal al-

\footnotetext{
${ }^{1}$ Sofyan Rofi. Analisis Perbedaan Hasil Belajar Siswa Mengikuti Program Tahfidz alQur'an (Studi Kasus Di SMP Muhammadiyah 9 Watukebo Jember). Tarlim: Jurnal Pendidikan Agama Islam). 2019. hlm.5.
} 
Qur'an terhadap hasil belajar mahasiswa IAIN Ambon program studi PAI angkatan 2017-1018 dengan memperoleh nilai hasil uji regresi linier sederhana dengan nilai constant sebesar 2,639, sedangkan nilai menghafal al-Qur'an sebesar 0,016. Dengan kriteria pengujian hipotesis adalah jika thitung $\geq t_{\text {tabel }}$ maka Ha diterima dan Ho ditolak. Dan jika thitung $\leq$ tabel maka Ha ditolak dan Ho diterima. Dengan demikian dapat ditarik kesimpulan bahwa Ha diterima dan Ho ditolak dengan memperoleh nilai

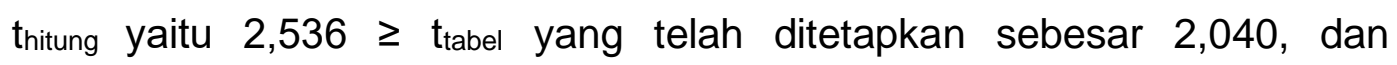
memperoleh besarnya pengaruh menghafal al-Qur'an terhadap hasil belajar adalah sebesar 17,2 \% dan sisanya yaitu 82,8\% dipengaruhi oleh faktor lain yang tidak diteliti dalam penelitian ini. Keberhasilan dalam meraih hasil belajar yang memuaskan dan terus meningkat sangat didukung oleh faktor internal dan faktor eksternal. Kegiatan menghafal alQur'an memberikan dampak positif yang menjadi faktor pendukung keberhasilan dalam belajar seperti kemampuan ketajaman otak, kedisiplinan dalam belajar, daya ingat yang baik, meningkatkan pola pikir yang baik dan kemudahan dalam memahami materi pembelajaran.

\section{DAFTAR PUSTAKA}

[1] Abdulwaly, Cece. (2019). Rahasia Dibalik Hafalan Para Ulama, Yogyakarta: Laksana.

[2] Al-Asfahani, Ar-Raghib. (2010). Mu'jam Mufradat alFaz al-Qur'an, Beirut: Dar Al-Fikr.

[3] Al-Hafizh, Ahsin W. (2005). Bimbingan Praktis Menghafal al-Qur'an, Jakarta: Bumi Aksara.

[4] An-Nahlawi, Abdurrahman. (2004). Pendidikan Islam di Rumah sekolah dan Masyarakat, Jakarta: Gema Insani.

[5] Anwar, Desi. (2003). Kamus Lengkap Bahasa Indonesia, Surabaya: Amelia.

[6] Baharuddin, (2010). Psikologi Pendidikan, Jogjakarta: Ar Ruzz Media. 
[7] Burhanuddin Dkk. (2019). Guru Mari Kita Menulis Penelitian Tindakan Kelas (PTK), Yogyakarta: Deepublish.

[8] Chairani Lisya dan M. A. Subandi. (2010). Psikologi Santri Penghafal Al-Qur'an: Peranan Regulasi Diri. Yogyakarta: Pustaka Pelajar.

[9] Elmubarok, Zaim. (2009). Membumikan Pendidikan Nilai: Mengumpulkan yang Terserak, Menyambung yang Terputus dan Menyatukan yang Tercerai, Bandung: Alfabeta.

[10] Fathurrohman, Muhammad dan Sulistyorini. (2012). Belajar dan Pembelajaran: Meningkatkan Mutu Pembelajaran Sesuai Standar Nasional, Yogyakarta: Teras.

[11] Fitriyani, Dina. (2016). Pengaruh Aktivitas Menghafal al-Qur'an Terhadap Kecerdasan Spiritual Santri di Pondok Pesantren AnakAnak Tahfidzul Qur'an (PPATQ) Raudlatul Falah Bermi Gembong Pati Tahun 2016, Semarang: UIN Walisongo Semarang.

[12] Gulo, W. (2000). Metode Penelitian, Jakarta: PT. Grasindo.

[13] Hasbullah. (2003). Dasar-Dasar Ilmu Pendidikan, Jakarta: PT. Raja Grafindo Persada.

[14] Ichwan, M. Nor. (2001). Memasuki Dunia al-Qur'an, Semarang: Effhar Offset Semarang.

[15] Kementerian Agama RI. (2015). Al-Qur'an dan Terjemahnya, Surabaya: Fajar Mulya.

[16] Ma'ruf, Amar. (2019). Skripsi: Pengaruh Menghafal al-Qur'an Terhadap Hasil Belajar Siswa Di Mi Tahfidzul Quran Kecamatan Biringkanaya Kota Makassar, Makassar: Universitas Muhammadiyah Makassar.

[17] Mahmud. (2010). Psikologi Pendidikan, Bandung: Pustaka Setia.

[18] Maksum. (2013). Syukran dan Wahidi, Beli surga dengan al-Qur'an (Media Pressindo. 
[19] Mappeasse, M. Yusuf. (2009). Pengaruh Cara dan Motivasi Belajar Terhadap Hasil Belajar Programmable Logic Controller (PLC) Siswa Kelas III jurusan Listrik SMK Negeri 5 Makassar. Jurnal Mepdek.

[20] Mulyasa, E. (2013). Pengembangan dan Implementasi Kurikulum 2013, Bandung: PT. Remaja Rosdakarya.

[21] Purnama, Yulian. (2020). https://muslimah.or.id/6222-mengapaperlu-Menghafal-al-Quran-1.html, Diakses: Jumat, 20 Maret 2020, Jam 09:25.

[22] Purwanto. (2012). Metodologi Penelitian Kuantitatif Untuk Psikologi dan Pendidikan, Yogyakarta: Pustaka Belajar.

[23] Rauf, Abdul Aziz Abdul. (2004). Kiat Sukses Menjadi Hafidz Qur'an Da'iyah, Bandung: PT Syaamil Cipta Media.

[24] Rofi, Sofyan. (2019). Analisis Perbedaan Hasil Belajar Siswa Mengikuti Program Tahfidz al-Qur'an (Studi Kasus Di SMP Muhammadiyah 9 Watukebo Jember). Tarlim: Jurnal Pendidikan Agama Islam.

[25] Sa'dulloh. (2013). 9 Cara Praktis Menghafal al-Qur'an, Cet. IV, (Jakarta: Gema Insani.

[26] Sugiyono. (2017). Metode Penelitian Pendidikan, Bandung: Alfabeta.

[27] Susanto, Ahmad. (2013). Teori Belajar dan Pembelajaran di Sekolah Dasar, Jakarta: Prenada Media Group.

[28] Syaodih, Nana. (2009). Metode Penelitian Pendidikan, Bandung: PT Remaja Rosdakarya.

[29] Tim Penyusun Pusat Bahasa. (2007). Kamus Besar Bahasa Indonesia, Jakarta: Balai Pustaka.

[30] Wahid, Wiwi Alawiyah. (2014). Cara Cepat Menghafal Al-Qur'an, Jogjakarta: DIVA Press.

[31] Wajdi, Farid. (2008). Tesis: “Tahfidz al-Qur’an Dalam Kajian ‘Ulum al-Qur'an", Jakarta: UIN Syarif Hidayatullah Jakarta. 